EDUKACJA MIĘDZYKULTUROWA

2012, nr 1

ISSN 2299-4106

JolANTA MusZyŃSKa

\title{
Percepcja społeczna Innego kulturowo w przestrzeni wschodniego pogranicza Polski
}

Streszczenie: Artykuł porusza kwestie percepcji Innego kulturowo w społecznościach lokalnych jednorodnych i zróżnicowanych pod względem kulturowym. Głównym odniesieniem są tu badania przeprowadzone wśród młodzieży licealnej dwóch społeczności lokalnych o odmiennej rzeczywistości społeczno-kulturowej. Zaprezentowane wyniki badań dotyczą przede wszystkim kwestii poziomu dystansu społecznego w odniesieniu do różnych sytuacji społecznego funkcjonowania z Innym kulturowo.

Słowa kluczowe: Inny kulturowo, społeczność lokalna, tożsamość, dystans społeczny, pogranicze.

Każde społeczeństwo zajmuje określony „obszar”, ten obszar w przeszłości, teraźniejszości i zapewne przyszłości był, jest i będzie miejscem spotkania z Innymi. Owi Inni przychodzą z bagażem swojej kultury, religii. Wszystko to sprawia, że większość współczesnych społeczeństw w ten czy inny sposób doświadcza wielokulturowości. Owe doświadczanie wielokulturowości najbardziej wyraźne staje się na pograniczu.

Granica jest czymś, co jednoznacznie dzieli, pogranicze zaś czymś, co pozwala owej jednoznaczności „łagodnieć”. Dawniej tereny pogranicza określano mianem rubieży, kresów. Na ziemiach położonych między Niemnem a Bugiem nigdy nie dominowała jedna kultura. Tereny te zamieszkiwała ludność mazowiecka, ludność pochodzenia bałtyckiego (Jaćwingowie) oraz litewska na wschodzie ${ }^{1}$. Na początku XI wieku ziemie zasiedlone przez Mazowszan opanowali książęta ruscy, którzy na zdobytych terenach wznieśli swoje osady: Mielnik, Drohiczyn, Suraż. Pod grodami takimi, jak Bielsk, Brańsk, zbudowanymi przez polskich książąt osiedlała się ludność ruska przybyła z Wołynia.

1 J. Wiśniewski: Zarys dziejów osadnictwa wiejskiego we wschodniej części województwa białostockiego do połowy XVII wieku. „Navukovy Zbornik” 1964, BTSK, s. 32. 
Oprócz etnicznych różnic, istotne były również różnice wyznaniowe uwidocznione po Wielkiej Schizmie (1054 r.).

Owa różnorodność etniczna, narodowościowa, religijna, wyznaniowa i językowa występuje na tych terenach do dziś. Północna część obecnego województwa podlaskiego (Suwałki i okolice) to miejsce zamieszkania autochtonicznej ludności litewskiej, wschodnia część to w dużej mierze ludność autochtoniczna białoruska, ukraińska. Dopełnieniem owej mozaiki narodowościowej są Tatarzy polscy, Romowie oraz pamiątki po narodzie żydowskim. Wyznaniowo również Podlasie jest zróżnicowane, zachodnie bardziej katolickie, a wschodnie bardziej prawosławne.

Różnorodność wyznaniowa Podlasia widoczna jest poprzez funkcjonujące obok siebie cerkwie, kościoły, zbory protestanckie, meczety i synagogi. Mimo iż w wielu miejscach nie ma śladów materialnych bytności Żydów, to pamięć o nich trwa w myśl zasady, iż obowiązkiem tych, którzy zostali jest pamięć o tych, którzy odeszli. Polifoniczność kultury pogranicza zdaje się być fenomenem owego obszaru. Wielość głosów kultur tworzy niepowtarzalny chór, gdzie każdy z uczestników ma szansę usłyszeć siebie i słuchać innych.

Inni przynależni do przeszłości, teraźniejszości i przyszłości dani są nam w różnych wzorach i postaciach. Badania wskazują, iż zarówno forma, jak i treść umysłowych reprezentacji wyznaczają istotne cechy naszych zachowań wobec Innych (badania nad następstwami posługiwania się wyobrażeniami bądź pojęciowymi wizjami siebie i Innych) ${ }^{2}$.

Innym jest się ze względu na rozmaite cechy: biologiczne, fizyczne, kulturowe (językowe, obyczajowe, religijne, zawodowe) ${ }^{3}$. Gdyby nie było Innych, to "należało by ich stworzyć" jest relacjąa ${ }^{5}$ Różnice kulturowe, narodowe stają się dopiero wyraziste w porównaniu, odniesieniu do Innych.

2 M. Wiczno: Dwa kody - dwa światy? Czyli o tym, co może wyniknać z odmiennej genezy kodów: percepcyjno-wyobrażeniowych i stowno-twierdzeniowych. W: M. Jarymowicz (red.): Poza egocentryczna perspektywa widzenia siebie i świata. Warszawa 1994, IP PAN.

3 E. Tarkowska: Niepewność kulturowa a stosunek do inności. W: M. Kempny, A. Kapciak, S. Łodziński (red.): U progu wielokulturowości. Warszawa 1997, Warszawa 1997, Oficyna Naukowa, s. 89.

4 Z. Bauman: Etyka ponowoczesna. Warszawa 1996, PWN, s. 214.

5 A. Hertz: Socjologia nieprzedawniona: wybór publicystyki. Warszawa 1992, PIW, s. 159 . 
Chciałabym zaprezentować fragment wyników badań własnych przeprowadzonych wśród młodzieży licealnej, zamieszkałej w dwóch miejscowościach wschodniego pogranicza: w Knyszynie i w Bielsku Podlaskim ${ }^{6}$. Przeszłość obu społeczności w kontekście relacji z odmiennością kulturową jest podobna, natomiast teraźniejszość zupełnie odmienna. Knyszyn obecnie jest miasteczkiem jednorodnym kulturowo i wyznaniowo, zaś Bielsk Podlaski wielokulturowym i wielowyznaniowym. Owa odmienność obu miejscowości skłoniła mnie do podjęcia badań dotyczących społecznej percepcji Innego kulturowo. Zaprezentuję wyniki badań dystansu społecznego młodzieży tych dwóch społeczności lokalnych w stosunku do Innego kulturowo.

Założenia badawcze atrybutów inności kulturowej przyjęto w oparciu o teorię atrybutów kryterialnych i korelatywnych Pawła Boskiego ${ }^{7}$. Zdaniem autora, atrybutami kryterialnymi określającymi tożsamość narodową są wiedza o symbolach kulturowych i znaczenie im ewentualnie przypisywane ${ }^{8}$. Natomiast zachowania odzwierciedlające założenia normatywne $i$ wartości danej kultury ${ }^{9}$ stanowią atrybuty korelatywne. W tym kontekście za atrybuty

6 Badaniami zostali objęci uczniowie trzecich klas liceów ogólnokształcących - Liceum Ogólnokształcącego nr 4 w Bielsku Podlaskim i Zespołu Szkół Ogólnokształcących w Knyszynie. Dobór badanych grup był celowy, ze względu na miejsce (środowisko lokalne różnorodne pod względem kulturowym - Bielsk Podlaski; środowisko lokalne jednorodne pod względem kulturowym - Knyszyn) oraz fazę rozwoju - wczesny okres dorosłości. W przypadku Knyszyna wybór tej, a nie innej szkoły był uwarunkowany tym, że na terenie Knyszyna funkcjonuje tylko jedna tego typu placówka oświatowa. Natomiast w przypadku Bielska Podlaskiego wybór LO nr 4 był podyktowany próbą zobiektywizowania rzeczywistości. W Bielsku funkcjonują dwa inne LO, lecz jedno z nich, to liceum z białoruskim językiem nauczania, natomiast drugie (LO im. T. Kościuszki) jest postrzegane przez społeczność lokalną jako liceum „typowo polskie”. Ponieważ dobór badanej grupy był celowy (społeczność lokalna jednorodna kulturowo i różnorodna kulturowo; okres życia - faza wczesnego wieku dorosłego) badaniami objęto 58 uczniów z IV Liceum Ogólnokształcącego w Bielsku Podlaskim (dwie klasy III) i 51 uczniów z Liceum Ogólnokształcącego w Knyszynie (dwie klasy III) - razem 109 osób. W obu szkołach funkcjonują tylko po dwie klasy trzecie.

7 P. Boski: O byciu Polakiem w ojczyźnie i o zmianach tożsamości kulturowo-narodowej na obczyźnie. W: P. Boski, M. Jarymowicz, H. Malewska-Peyre: Tożsamość a odmienność kulturowa. Warszawa 1992, IP PAN, s. 71-164.

8 Tamże, s. 92.

9 Tamże, s. 93. 
kryterialne w prowadzonych badaniach uznano język, wyznanie i narodowość jako elementy kultury symbolicznej.

Język jest podstawowym składnikiem kultury i zasadniczym narzędziem komunikacji między ludźmi. Zdaniem Jerzego J. Smolicza ${ }^{10}$ język może być traktowany jako rdzeń poszczególnych kultur. Język i wyznanie to dwie charakterystyczne sfery odróżniające ludzi od siebie, np. język wyróżnia polskich imigrantów we Francji, a religia (wyznanie) irlandzkich imigrantów w Angliii ${ }^{11}$ W przeprowadzonych badaniach przyjęto założenie, iż Inny to ktoś, kogo wyróżnia język, religia-wyznanie, narodowość. Określenie poziomu znaczenia każdego z atrybutów Inności kulturowej pozwoliło na dookreślenie postrzegania Innego kulturowo jako członka społeczności lokalnej.

Można wyróżnić języki znormalizowane i nieznormalizowane, urzędowe i nieurzędowe, język większości i języki mniejszości, języki silne kulturowo i słabe ${ }^{12}$. Na obszarze wschodniego pogranicza Polski, oprócz języka polskiego (znormalizowanego, urzędowego, silnego kulturowo), używany jest język białoruski i język ukraiński. W codziennym użyciu, zwłaszcza wśród mieszkańców południowo-wschodniej części województwa podlaskiego, są odmiany (dialekty) języka białoruskiego i ukraińskiego, przez społeczność określane językiem „prostym”.

W związku z tym w przyjętym postępowaniu badawczym nie sprecyzowano konkretnie, o jaki język chodzi. Poproszono respondentów o wyrażenie swojej opinii w siedmiostopniowej skali w stosunku do następujących twierdzeń: Gdyby chcieli uczyć się swojego języka, to bytbym przeciwny temu; Uwa$\dot{z} a m, \dot{z}$ moga postugiwać się swoim językiem $w$ domu, lecz $w$ miejscach publicznych powinni używać mojego języka. Ustalono trzy kategorie dystansu wobec języka Innego kulturowo, których konsekwencją jest społeczna akceptacja lub brak funkcjonowania Innego kulturowo jako członka społeczności lokalnej.

Mały dystans wobec języka Innego kulturowo oznacza zgodę na naukę języka Innego kulturowo w szkole oraz posługiwanie się nim w miejscach pub-licznych. Taką deklarację złożyło 46\% badanej młodzieży w Bielsku Podlaskim i tylko 17\% młodzieży w Knyszynie. Średni dystans wobec języka Innego

10 J. J. Smolicz: Język jako wartość rdzenna. W: A. Kłoskowska (red.): Oblicza polskości. Warszawa 1990, UW, Program Badań i Współtworzenia Filozofii Pokoju, s. 121-213.

11 A. Kłoskowska: Kultury narodowe u korzeni. Warszawa 1996, PWN, s. 21.

12 J. M. Tortosa: Polityka językowa a języki mniejszości: od Wieży Babel do daru jęzków. Warszawa 1986, PIW, s. 9. 
kulturowo w Bielsku Podlaskim reprezentowało 32\% badanych, w Knyszynie zaś 55\%. Jak można przypuszczać, warunkowane jest to brakiem wyraźnego określenia języka. W przyjętych zamierzeniach badawczych nie chodzi o Innego w kontekście określonej kultury, lecz o Innego kulturowo w ogóle. Duży dystans wobec języka Innego w Bielsku Podlaskim prezentowało 22\% respondentów, natomiast w Knyszynie 28\%.

Istotność różnic statystycznych $\left(\chi^{2}=20,15 ; \mathrm{df}=2 ; \mathrm{p}=4 \mathrm{E}-05\right)$, jak również wartość współczynnika kontyngencji $C_{\text {kor }}=0,40$ sugeruje umiarkowaną siłę związku między zmiennymi. Wyniki badań w formie graficznej prezentuje wykres 1.

Wykres 1. Dystans wobec języka Innego kulturowo

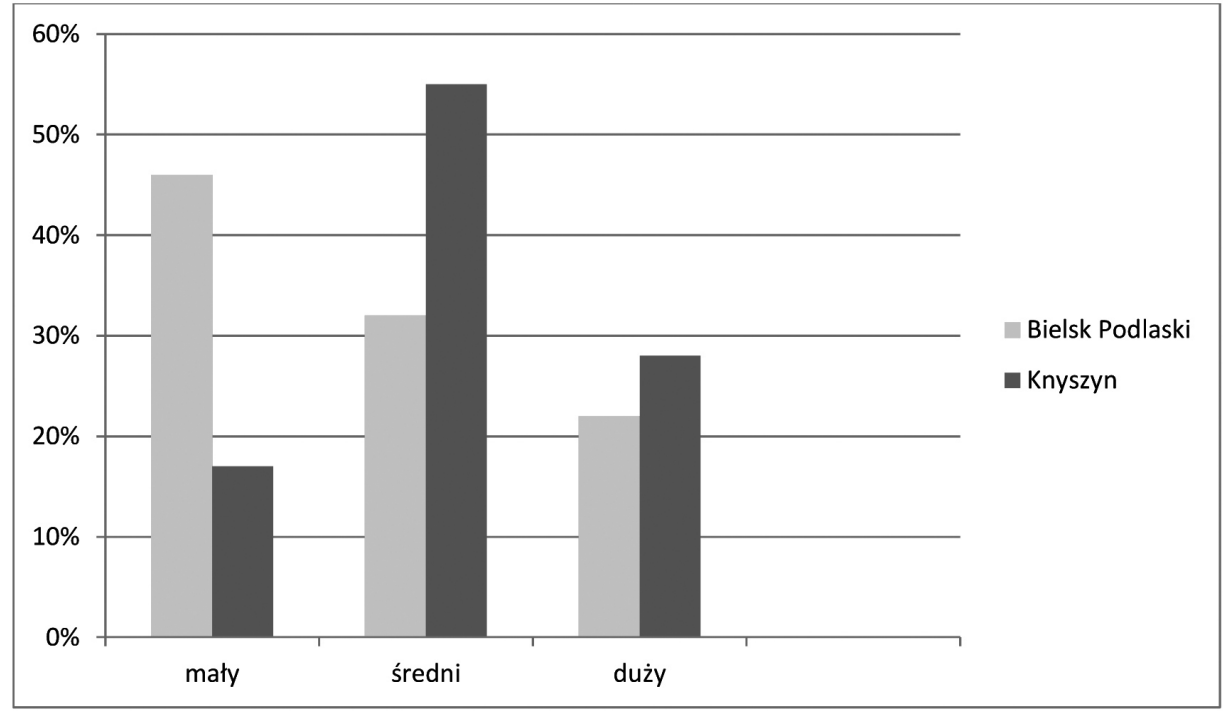

Źródło: badania własne.

W przypadku określenia znaczenia wyznania Innego kulturowo dla jego aprobaty bądź dezaprobaty funkcjonowania w społeczności lokalnej zasugerowano trzy wyznania chrześcijańskie. Podyktowane było to faktem, iż ich wyznawcy są mieszkańcami północno-wschodniej Polski, istnieje zatem duże prawdopodobieństwo kontaktu z nimi w środowisku lokalnym.

Wprowadzając hipotetyczną sytuację: Wyobraź sobie, że do Twojej miejscowości przyjeżdza grupa ludzi, która postuguje się innym niż Wasza spo- 
teczność językiem, jest innej narodowości, wyznania - z zamiarem osiedlenia się w niej poproszono respondentów o dokonanie wyboru: Gdybym mógt wybierać, to chciat(a)bym, by byli to ludzie wyznania: katolickiego, prawostawnego, protestanckiego w stosunku do każdego z podanych wyznań. Przyjęto (rozkład empiryczny), że atrybut kryterialny „wyznanie” jest interpretowany w kategoriach „znaczący”, „nieokreślony” - rozumiany jako brak jednoznaczności o opinii badanych oraz "nieznaczący” jako nieistotny w społecznym odbiorze Innego.

Stwierdzono, iż w przypadku respondentów z Bielska Podlaskiego jedynym wyznaniem, które ma duże znaczenie jako kryterium braku społecznej akceptacji jest wyznanie protestanckie (23\%). W Knyszynie, analogicznie jak w Bielsku Podlaskim, było to również wyznanie protestanckie (46\%), kolejnym zaś wyznanie prawosławne (34\%). Wydaje się, iż jest to konsekwencja stereotypowego widzenia wyznania protestanckiego przez pryzmat Świadków Jehowy, Zielonoświątkowców, obecna nie tylko w badanych społecznościach. Zaś w przypadku dużego dystansu do wyznawców prawosławia w Knyszynie przypuszczalnie wynika po pierwsze z braku kontaktu w środowisku lokalnym, a po drugie z „tradycji grupy” (podczas zaboru rosyjskiego dla potrzeb armii rosyjskiej wzniesiono w Knyszynie cerkiew).

Tabela 1. Wyznanie Innego kulturowo i jego społeczne znaczenie (dane w procentach)

\begin{tabular}{|l|c|c|c|c|c|c|}
\hline \multirow{2}{*}{ Kategorie } & \multicolumn{3}{|c|}{ Bielsk Podlaski } & \multicolumn{3}{c|}{ Knyszyn } \\
\cline { 2 - 7 } & prawosławni & katolicy & protestanci & prawosławni & katolicy & protestanci \\
\hline „Znaczący” & 0 & 0 & 23 & 34 & 0 & 46 \\
\hline „Nieokreślony” & 39 & 78 & 62 & 66 & 24 & 54 \\
\hline „Nieznaczący” & 61 & 22 & 15 & 0 & 76 & 0 \\
\hline Ogółem & 100 & 100 & 100 & 100 & 100 & 100 \\
\hline
\end{tabular}

Źródło: badania własne.

Przy określeniu poziomu znaczenia narodowości Innego kulturowo, analogicznie jak w przypadku wyznania, w kontekście tej samej hipotetycznej sytuacji, poproszono badaną młodzież o ustosunkowanie się do twierdzenia: Sadzę, że dobrze bytoby, gdyby na terenie naszej miejscowości osiedlili się; następnie podano listę narodowości. 
Tabela 2. Dystans etniczny wobec Innego kulturowo (dane w procentach)

\begin{tabular}{|l|r|r|r|r|r|r|}
\hline \multirow{2}{*}{ Narodowość } & \multicolumn{3}{|c|}{ Bielsk Podlaski } & \multicolumn{3}{c|}{ Knyszyn } \\
\cline { 2 - 7 } & Mały & Średni & Duży & Mały & Średni & Duży \\
\hline Białorusini & 19 & 81 & 0 & 0 & 59 & 41 \\
\hline Litwini & 0 & 77 & 23 & 0 & 51 & 49 \\
\hline Ukraińcy & 10 & 69 & 21 & 2 & 68 & 29 \\
\hline Niemcy & 29 & 63 & 8 & 32 & 41 & 27 \\
\hline Anglicy & 50 & 40 & 10 & 49 & 39 & 12 \\
\hline Amerykanie & 48 & 42 & 10 & 56 & 29 & 15 \\
\hline Romowie & 0 & 48 & 52 & 0 & 54 & 46 \\
\hline $\begin{array}{l}\text { Innej narodowości, } \\
\text { lecz z pochodzenia Polacy }\end{array}$ & 46 & 27 & 8 & 59 & 39 & 2 \\
\hline
\end{tabular}

Źródło: badania własne.

Dane zawarte w tabeli 2 jednoznacznie wskazują, iż w obu badanych grupach narodowością zdecydowanie nieakceptowaną w społeczności lokalnej są Romowie (Bielsk Podlaski 52\% badanych, w Knyszynie 46\%). Respondenci z Knyszyna wykazali również duży dystans wobec Litwinów - 49\% badanych i Białorusinów - 41\% badanych. Można przypuszczać, iż warunkowany jest on brakiem wiedzy i możliwości kontaktu, a odwołujący się tylko do wiedzy stereotypowej. Duży dystans wobec Białorusinów wśród badanych w Knyszynie jest swoistą konsekwencją dystansu wobec wyznania prawosławnego. Badania przeprowadzone przez Andrzeja Sadowskiego ${ }^{13}$ oraz Elżbietę Czykwin ${ }^{14}$ wskazują siłę stereotypizacji, stygmatyzacji owej grupy w kontekście wyznaniowym. W obu badanych grupach zdecydowanie preferowane jako członkowie społeczności lokalnej byłyby osoby „innej narodowości, lecz z pochodzenia Polacy" - Knyszyn 65\% badanych, a w Bielsku Podlaskim 59\%. Mały dystans badani wykazali również wobec Anglików i Amerykanów. W Bielsku Podlaskim bardziej preferowani byli Anglicy (50\% badanych), w Knyszynie natomiast Amerykanie (48\% badanych). Należałoby tu wspomnieć, iż swoistą „tradycją" społeczności knyszyńskiej są wyjazdy do Stanów Zjednoczonych,

13 A. Sadowski: Narody wielkie i małe. Białorusini w Polsce. Kraków 1991, UJ.

14 E. Czykwin: Białoruska mniejszość narodowa jako grupa stygmatyzowana. Białystok 2000, „Trans Humana”. 
dające prestiż społeczny, stąd też - jak można przypuszczać - nadal jest tu obowiązujący „mit Ameryki” jako „raju”. Przypuszczalnie również takie preferencje badanej młodzieży są konsekwencją „macdonalizacji” społeczeństwa i dominacji kultury anglosaskiej, obecnej w każdej sferze życia młodego człowieka. W pewnej mierze potwierdziły to również badania Jerzego Nikitorowicza $^{15}$. Na pytanie o kraj, w którym młodzież chciałaby zamieszkać i podjąć pracę, większość respondentów z Polski wskazywało USA.

Interesujące $\mathrm{z}$ badawczego punktu widzenia wydało się stwierdzenie, jak traktowany jest Inny kulturowo jako członek społeczności lokalnej. Poproszono respondentów o ustosunkowanie się do następujących twierdzeń: Ponieważ oni tu przyjechali, to powinni podporzadkować się prawom i zasadom funkcjonowania naszej społeczności. Nie zgodził(a)bym się na kultywowanie przez nich tradycji zwiazanych z ich kultura i religia. Sadzę, że byt(a)bym przeciw temu, by mogli wznieść światynię swojego wyznania, poprzez oznaczenie w siedmiostopniowej skali ich opinii. Ustalono w odniesieniu do empirycznego rozkładu wyników trzy poziomy przyznawania praw Innemu kulturowo jako członkowi społeczności lokalnej. Były to: przyznanie takich samych praw jak pozostałym; częściowe ograniczenie praw oraz catkowite ograniczenie praw.

Wyniki przedstawione na wykresie 2 jednoznacznie wskazują, iż młodzież w Bielsku Podlaskim Innemu kulturowo przyznaje takie same prawa, jak pozostałym członkom społeczności lokalnej. Taką odpowiedź podało $69 \%$ badanych. Jak sądzę, jest to efekt współistnienia i współpracy wielu pokoleń, które od zawsze miały stały bezpośredni kontakt z Innym kulturowo. Został on niejako wpisany w „krajobraz” społeczności lokalnej, nie jest postrzegany w kategorii „obcy” lecz „tutejszy”. Współczesna młoda artystka - grafik Małgorzta Trochniuk, wychowana w małej miejscowości pod Bielskiem Podlaskim stwierdziła: „[...] świat mojego dzieciństwa to świat białoruski, polski, ukraiński. Nie myśleliśmy o sobie samych jako obcych, po prostu wszyscy byliśmy tutejsi [...]"16. Taki stan rzeczy potwierdzają również badania Sadowskiego ${ }^{17}$. Zupełnie odwrotną sytuację możemy zaobserwować w Knyszynie. Tu aż 52\% badanej młodzieży stwierdziło, iż Inny kulturowo powinien podpo-

15 J. Nikitorowicz: Mtodzież pogranicza kulturowego Polski, Białorusi i Ukrainy wobec integracji europejskiej. Białystok 2000, „Trans Humana”, s. 112.

16 Wywiad zamieszczony w „Wysokich obcasach”, dodatku do „Gazety Wyborczej” wrzesień 2001.

17 A. Sadowski: Pogranicze polsko-białoruskie. Tożsamość mieszkańców. Białystok 1995, „Trans Humana”. 
rządkować się woli pozostałych członków społeczności lokalnej. W potocznej

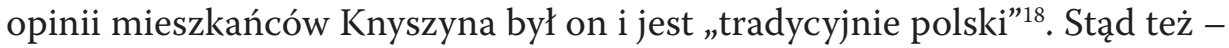
jak można przypuszczać - wola podtrzymania takiej tradycji stała się w tym przypadku czynnikiem decydującym. Istotne różnice statystyczne $\left(\chi^{2}=95,99\right.$; $\mathrm{df}=2 ; \mathrm{p}=1 \mathrm{E}-21)$ oraz współczynnik kontyngencji $\mathrm{C}_{\mathrm{kor}}=0,72$ zdają się potwierdzać fakt dużej zależności w przyznawaniu praw Innemu kulturowo od środowiska lokalnego.

Wykres 2. Przyznawanie praw Innemu kulturowo jako członkowi społeczności lokalnej

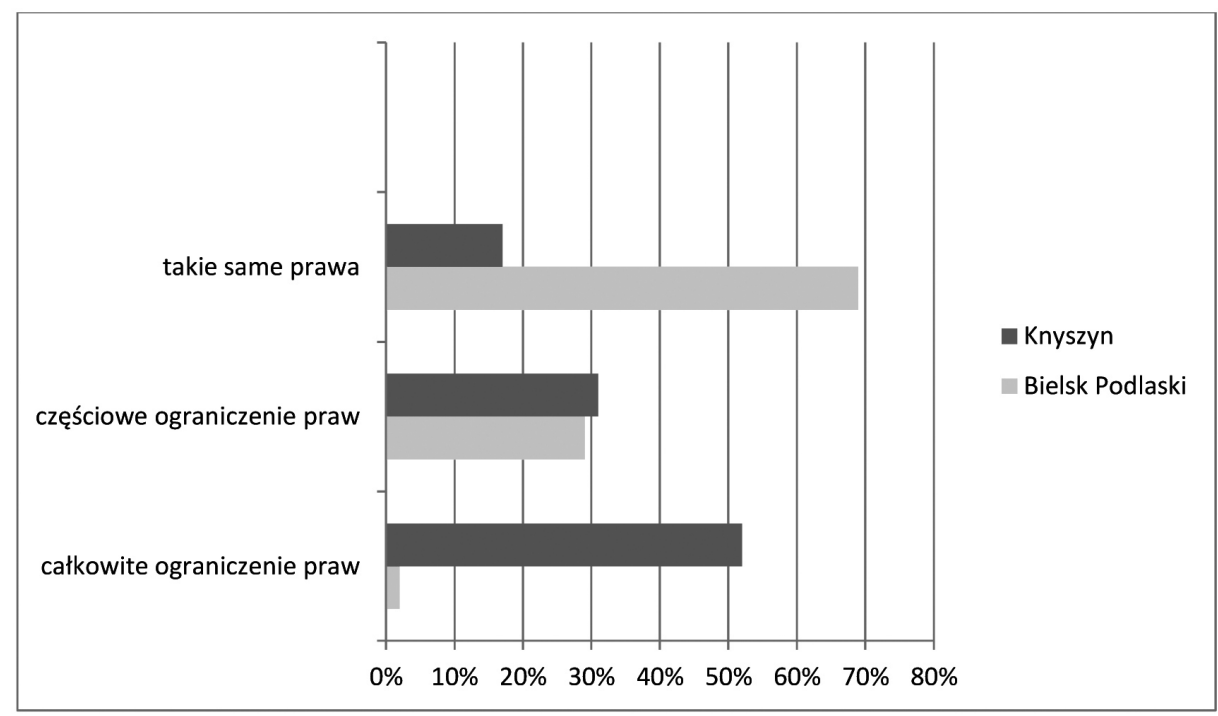

Źródło: badania własne.

Kolejnym podjętym wątkiem przeprowadzonych badań było poznanie dystansu wobec Innego kulturowo jako sąsiada i przyjaciela. Dystans społeczny w literaturze interpretowany jest jako stopień bliskości lub separacji pomiędzy poszczególnymi osobami lub grupami w szerszej zbiorowości. Może on istnieć obiektywnie lub jedynie w świadomości jednostek ${ }^{19}$.

18 Z rozmów z mieszkańcami Knyszyna przeprowadzonych w trakcie badań terenowych w 2000 roku.

19 K. Olechnicki, P. Załęcki: Stownik socjologiczny. Toruń 1997, „Graffiti BC”, s. 51. 
Na podstawie ustosunkowania się do twierdzenia: Myślę, że gdyby ci ludzie zostali moimi sąsiadami, nie miał(a)bym nic przeciw temu określono poziom dystansu wobec Innego kulturowo jako sąsiada, przyjmując, że o małym dystansie świadczy akceptacja owej sytuacji wyrażająca się w deklaracji „zdecydowanie tak" i "tak"; o średnim poziomie brak sprzeciwu lub brak akceptacji, o dużym zaś sprzeciw wobec powyższego twierdzenia, charakteryzujący się odpowiedziami „nie” i „zdecydowanie nie”.

Wyniki badań pokazały, iż w Knyszynie 39\% respondentów nie chciałoby mieszkać obok kogoś, kto jest innej narodowości, wyznania, w Bielsku Podlaskim natomiast tylko $10 \%$ badanych wyraziło taką opinię. Duże dysproporcje między grupami są widoczne przy małym poziomie dystansu. Zgodę na taki stan rzeczy w Bielsku Podlaskim wyraziło 33\% badanych, w Knyszynie zaś 2\%. Można zatem sądzić, iż badana młodzież w Bielsku Podlaskim w dużej mierze jest w stanie zaakceptować Innego kulturowo jako sąsiada. Wydaje się być to bardzo prawdopodobne, ponieważ ów Inny bardzo często jest tym sąsiadem. Różnice statystyczne $\left(\chi^{2}=67,121 \mathrm{df}=2\right.$ p=3E-15) i wartość współczynnika kontyngencji $C_{\text {kor }}=0,63$ mówią o znacznej sile związku i zależności od środowiska lokalnego.

Wykres 3. Dystans społeczny wobec Innego kulturowo jako sąsiada

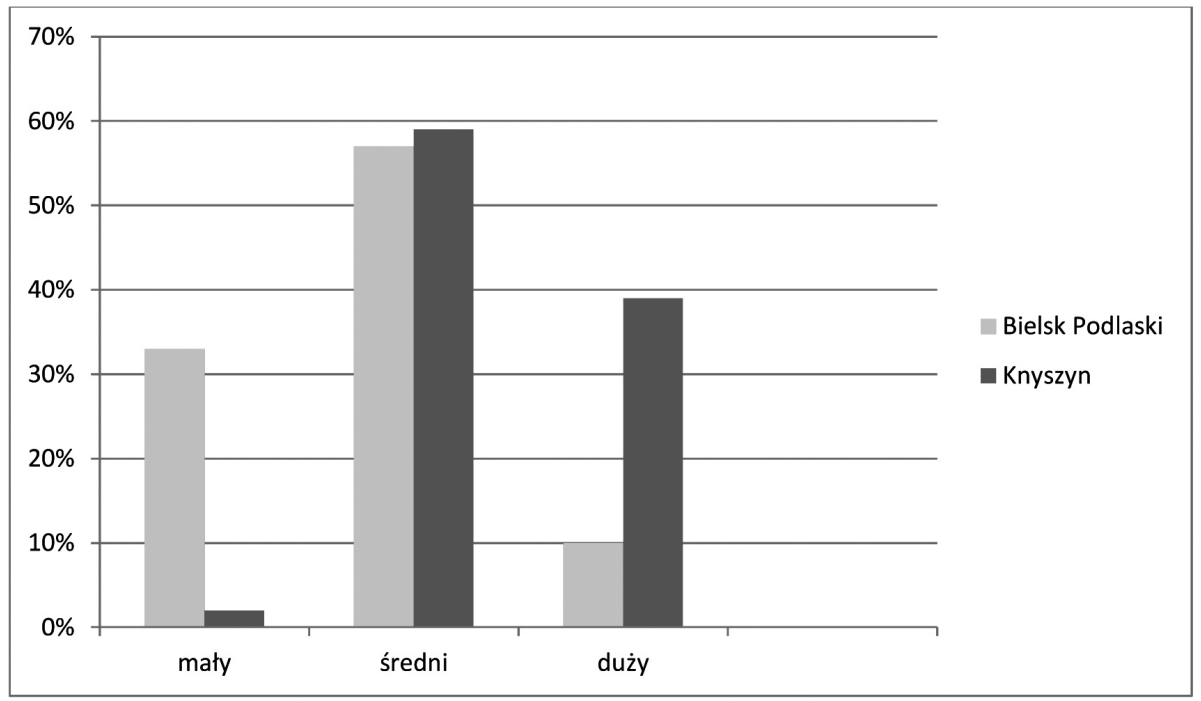

Źródło: badania własne. 
Analogicznie postąpiono w sytuacji określenia poziomu dystansu wobec Innego kulturowo jako przyjaciela, zamieszczając twierdzenie: Sądzę, że mógtbym/mogtabym się z nimi zaprzyjaźnić.

W tym przypadku młodzież badana z Bielska również wyraziła większą otwartość na inność. Tylko 8\% badanych wykazało duży dystans do Innego kulturowo jako przyjaciela. Natomiast w Knyszynie było to 20\% badanych. Jeszcze wyraźniej widać to w kontekście małego poziomu dystansu. Taki poziom w Knyszynie osiągnęło tylko 7\% badanej młodzieży, w Bielsku Podlaskim zaś 38\%. W obu grupach analogicznie do sytuacji dystansu wobec Innego kulturowo jako sąsiada największy procent respondentów zachował rezerwę (średni poziom dystansu). Wartość współczynnika kontyngencji $\mathrm{C}_{\mathrm{kor}}=0,45$ oraz różnice statystyczne $\left(\chi^{2}=27,514 \mathrm{df}=2 \mathrm{p}=1 \mathrm{E}-0,6\right)$ wskazują na niewielką siłę związku między badanymi zmiennymi.

Wykres 4. Dystans społeczny wobec Innego kulturowo jako przyjaciela

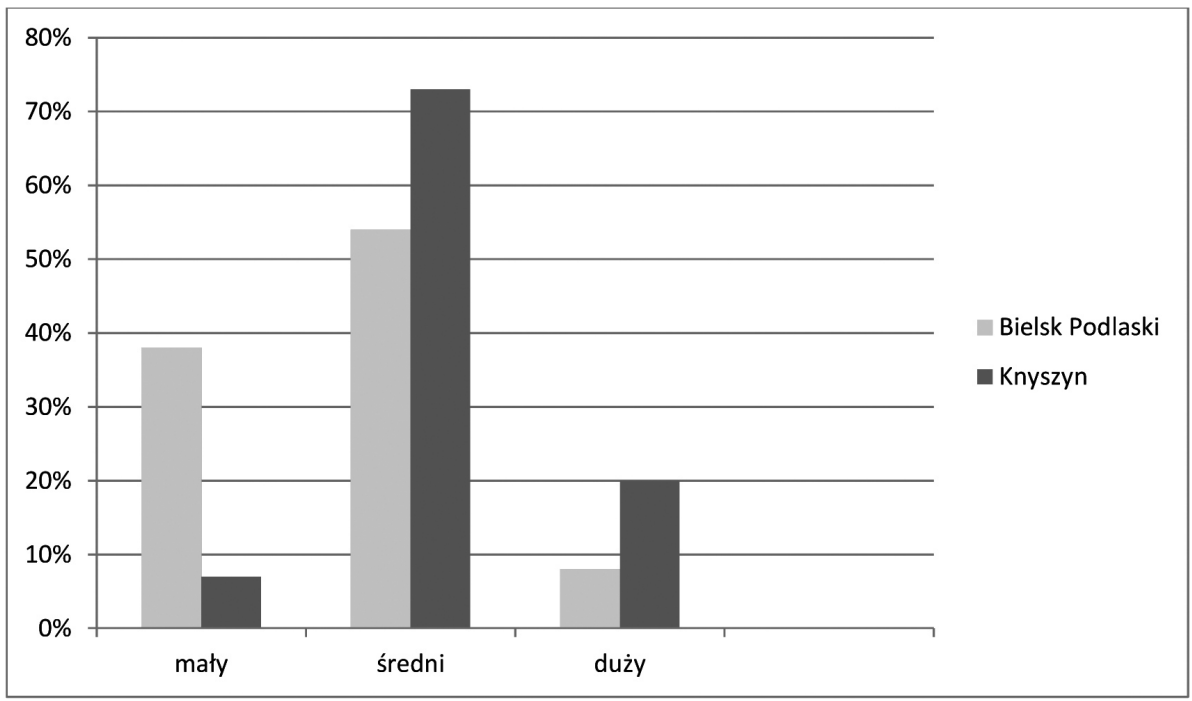

Źródło: badania własne.

\section{Wnioski}

Życie w świecie podobnych sprzyja iniekcji własnych stanów i generalizacji własnych doświadczeń, co sprawia, że ludzie wokół postrzegani są na podobieństwo „swoich” i traktowani tak, jak oni. W konsekwencji prowadzi 
to do włączenia obcych do swoich, a nie zrozumienia i zaakceptowania ich odrębności ${ }^{20}$. Konsekwencje podziału na swoich i obcych widoczne są w szeregu prawidłowości, takich jak: postrzeganie członków innych grup w sposób niezróżnicowany, poprzez kategorialne (apersonalne) ich traktowanie, bezwiedne sprzyjanie osobom o tej samej, co własna przynależności ${ }^{21}$.

Zaprezentowane wyniki badań sugerują, iż jednoznaczne określenie cech inności kulturowej jest warunkiem akceptacji społecznej lub jej braku wobec Innego kulturowo i staje się swoistą egzemplifikacją kategoryzacji społecznej, najbardziej widoczną w relacjach międzygrupowych ${ }^{22}$. Wyniki wskazują, iż młodzież w Bielsku Podlaskim w większości jest w stanie zaakceptować jako fakt społeczny różnice językowe i wyznaniowe, pewien wyjątek stanowi tu jednak dystans wobec osób wyznania protestanckiego. Natomiast respondenci z Knyszyna częściej zachowują duży dystans społeczny wobec języka Innego kulturowo oraz jego wyznania, w szczególności zaś wobec wyznania protestanckiego i prawosławnego.

Kategoryzacja jest mechanizmem przystosowania społecznego, występuje tutaj zjawisko redukcji informacji o innej grupie, co ułatwia przyswojenie schematu poznawczego, pomijającego różnice indywidualne. Informacje dotyczące ludzi należących do innej grupy związane są z wyróżnieniem cech osobowościowych i stanowią rozwinięcie schematu podstawowego, co w konsekwencji nie prowadzi do zmiany przyjętej kategoryzacji. Daje to również efekt porównywania w relacjach „my”-„oni”, gdzie „oni” zazwyczaj są gorzej postrzegani w świadomości ocenianych, a to pozwala na podwyższenie samooceny. Owe gorsze postrzeganie jest często wynikiem postrzegania stereotypowego, gdzie „przekonanie na temat innej grupy oraz jej członków, polega na przeniesieniu atrybutów kryterialnych oraz korelatywnych z poziomu osobistego i użyciu ich na społecznym poziomie percepcji”23.

20 M. Jarymowicz: Poznać siebie - zrozumieć innych. W: J. Kozielecki (red.): Humanistyka przełomu wieków. Warszawa 1999, „Żak”, s. 190-191.

21 H. Tajfel (red.): Differentiation Between Social Groups: Studies in the social psychology of intergroup relations. London 1978, Academic Press. Za: M. Jarymowicz: Poznać siebie - zrozumieć innych. W: J. Kozielecki (red.): Humanistyka przełomu wieków. cyt. wyd., s. 190-191.

22 G. W. Allport: The nature of prejudice. Cambridge 1954, Addison Wesley.

23 P. Boski: O byciu Polakiem w ojczyźnie i o zmianach tożsamości kulturowo-narodowej na obczyźnie. W: P. Boski, M. Jarymowicz, H. Malewska-Peyre: Tożsamość a odmienność kulturowa. cyt. wyd., s. 96. 
Teoria tożsamości społecznej Tajfela zakłada, iż ludzie są motywowani do utrzymania pozytywnej koncepcji siebie, która wynika w dużym stopniu z identyfikacji z grupą dzięki procesom porównań międzygrupowych. Pragnienie posiadania pozytywnego obrazu siebie i pozytywnej tożsamości społecznej stwarza motywacyjne podstawy do różnicowania międzygrupowego, możliwego dzięki procesowi kategoryzacji ${ }^{24}$.

Spotkanie z odmiennością u różnych osób, w zależności od ich doświadczeń społecznych i sposobu widzenia „My”, pociąga za sobą różne konsekwencje. Życie tylko wewnątrz własnej grupy i relacjach bezpośrednich może przesłaniać dostrzeganie innych grup tak bardzo, iż kształtowanie się pojęcia „My" odbywa się bez porównań międzygrupowych. Utrwalenie takiej „tradycji” grupy powoduje, że dostrzeganie odmienności innych ludzi pociąga za sobą silny dysonans i napięcia emocjonalne. Spostrzeganie odrębności wynika nie tyle z niechęci, co z niezdolności odniesienia do Innych własnego systemu norm. Wynika to z przeciwstawienia kategorii „MY-ONI”, a jest to konsekwencja zaklasyfikowania Innych do kategorii „nie-My”25.

Świat człowieka jest podzielony symboliczną granicą na to, co swoje, znane, bliskie i to, co obce, odległe, często budzące lęk. Wśród otaczających nas ludzi są ci, których zaliczamy do kategorii przyjaciół i ci, którzy są w opozycji do przyjaciół - wrogowie. Ta opozycja jest odzwierciedleniem przeciwstawieństwa między tym, co wewnątrz a tym, co na zewnątrz ${ }^{26}$. Podział naszego świata czyni go czytelnym, przyjaciół powołuje współpraca, wrogów walka. Dzięki takiej opozycji tworzą się ramy uspołecznienia. Przyjaciel i wróg należą do kategorii „swoich”. Przyjaciel jako znany nam i akceptowany, wróg również znany, bardziej znany niż Obcy, ponieważ nie wiemy, czego możemy doświadczyć. Staje się nieprzewidywalnym, niezaplanowanym Trzecim²7, staje się Innym, innym od przyjaciela, innym od wroga.

24 A. Kwiatkowska: Tożsamość a społeczne kategoryzacje. Warszawa 1999, IP PAN, S. 85.

25 M. Jarymowicz: Poznać siebie - zrozumieć innych. W: J. Kozielecki (red.): Humanistyka przełomu wieków. cyt. wyd., s. 194.

26 Z. Bauman: Etyka ponowoczesna. cyt. wyd., s. 79.

27 Tamże, s. 82. 


\section{Bibliografia}

Allport G. W.: The nature of prejudice. Cambridge 1954, Addison Wesley.

Bauman Z.: Etyka ponowoczesna. Warszawa 1996, PWN.

Boski P.: O byciu Polakiem w ojczyźnie i o zmianach tożsamości kulturowo-narodowej na obczyźnie. W: P. Boski, M. Jarymowicz, H. Malewska-Peyre: Tożsamość a odmienność kulturowa. Warszawa 1992, IP PAN.

Czykwin E.: Białoruska mniejszość narodowa jako grupa stygmatyzowana. Białystok 2000, „Trans Humana”.

Hertz A.: Socjologia nieprzedawniona: wybór publicystyki. Warszawa 1992, PIW.

Jarymowicz M.: Poznać siebie - zrozumieć innych. W: J. Kozielecki (red.): Humanistyka przełomu wieków. Warszawa 1999, „Żak”.

Kłoskowska A.: Kultury narodowe u korzeni. Warszawa 1996, PWN.

Kwiatkowska A.: Tożsamość a społeczne kategoryzacje. Warszawa 1999, IP PAN.

Nikitorowicz J.: Młodzież pogranicza kulturowego Polski, Białorusi i Ukrainy wobec integracji europejskiej. Białystok 2000, „Trans Humana”.

Olechnicki K., Załęcki P.: Stownik socjologiczny. Toruń 1997, „Graffiti BC”. Sadowski A.: Narody wielkie i małe. Białorusini w Polsce. Kraków 1991, UJ. Sadowski A.: Pogranicze polsko-białoruskie. Tożsamość mieszkańców. Białystok 1995, „Trans Humana”.

Smolicz J. J.: Język jako wartość rdzenna. W: A. Kłoskowska (red.): Oblicza polskości. Warszawa 1990, UW, Program Badań i Współtworzenia Filozofii Pokoju.

Tarkowska E.: Niepewność kulturowa a stosunek do inności. W: M. Kempny, A. Kapciak, S. Łodziński (red.): U progu wielokulturowości. Warszawa 1997, Oficyna Naukowa.

Tortosa J. M.: Polityka językowa a języki mniejszości: od Wieży Babel do daru języków. Warszawa 1986, PIW.

Tajfel H. (red): Differention between social group: Studies in the social psychology of intergroup relations. Londyn 1978. Za: M. Jarymowicz: Poznać siebie - zrozumieć innych. W: J. Kozielecki (red.): Humanistyka przełomu wieków. Warszawa 1999, „Żak”. 
Wiczno M.: Dwa kody - dwa światy? Czyli o tym, co może wyniknać z odmiennej genezy kodów: percepcyjno-wyobrażeniowych i słowno-twierdzeniowych. W: M. Jarymowicz (red.): Poza egocentryczna perspektywa widzenia siebie i świata. Warszawa 1994, IP PAN.

Wiśniewski J.: Zarys dziejów osadnictwa wiejskiego we wschodniej części województwa białostockiego do połowy XVII wieku. „Navukovy Zbornik” 1964, BTSK.

\section{Social perception of the culturally Different in the space of eastern borderlands of Poland}

\section{Summary}

The article explores the issues of perceiving the culturally Different in local communities, both culturally homogeneous and differentiated ones. What constitutes the main reference is the research carried out among upper-secondary school youth in two local communities of different socio-cultural reality. The presented results mostly concern the level of social distance with regard to different situations of social functioning with the culturally Different.

Translated by Agata Cienciała 